\title{
The subalpine and alpine flora of Mount Jaya (New Guinea): status and threats
}

\author{
T.M.A. Utteridge ${ }^{1}$, P.J. Edwards ${ }^{1}$
}

\section{Key words}

conservation

Indonesia

mining

Pteridophytes

\begin{abstract}
The highest mountains in South-East Asia are in the Sudirman range of Indonesian New Guinea; the highest is Mt Jaya which rises to $4884 \mathrm{~m}$ and is still partly glaciated. The geological history of the region has left it rich in mineral deposits and the alpine area is currently being mined for copper. In 1997 a project was initiated by the Royal Botanic Gardens, Kew, in conjunction with the mining companies Rio Tinto and PT-Freeport Indonesia, to study the region's flora. An introduction to the region, including geology, glaciation and past exploration will be given, as well as the history and objectives of the Kew project. During the project, Kew made several collaborative expeditions to the area, as well as a database of all historical collections from Mt Jaya. Collection patterns for different habitats have been analysed and show that the alpine areas have been adequately collected, but montane areas are still under-collected. A summary of the recently published floristic treatment of the c. 750 species found above $3000 \mathrm{~m}$, including many endemics, is presented, and the fern and fern allies are discussed in greater detail. The flora of Mt Jaya, as well as other tropical alpine floras, is under threat from mining activities and climate change,
\end{abstract} and these will be briefly discussed.

Published on 30 October 2009

\section{INTRODUCTION}

The Royal Botanic Gardens, Kew, working together with the PT-Freeport Indonesia (PT-FI) and Rio Tinto mining companies, has recently completed a checklist of the subalpine and alpine flora of Mt Jaya in New Guinea (Johns et al. 2006). Here, we give a brief background and introduction to the Mt Jaya region, describe the Kew project, and report on the published checklist giving information on the number of species etc. found during the project. The results of the project are of great significance, as the study area is bordered on the eastern side by the Lorentz National Park (a UNESCO World Heritage Area), and includes most of the vegetation types found within that National Park.

\section{Location}

The tropical island of New Guinea is one of the least explored regions and remaining wilderness areas on the planet (Mittermeier et al. 2003). Politically, the island is divided roughly down the middle into the Indonesian provinces of Papua and Papua Barat (collectively formerly known as Irian Jaya) on the west, and independent Papua New Guinea on the east. A central cordillera of high mountains divides the island into north and south with several peaks capped with glaciers until recently. The western end of the central cordillera ends with the Sudirman range, and here is found the highest peak in South-East Asia - Mt Jaya rising to $4884 \mathrm{~m}$.

\section{Exploration and mining}

The mountains of New Guinea were relatively unknown until the beginning of the 20th century, and Mt Jaya was first explored in 1913 but, though the glaciers were reached during that expedition, the summit was not climbed till 1936 by a Dutch team led by A.H. Colijn (see Ballard et al. 2002, for a detailed discussion and bibliography). During the Colijn expedition J.J. Dozy, the team's geologist, took a sample from a copper-rich ore body jutting out of the grassy plateau named Carstenszweide below the summit valleys. New Guinea's geological history has left the island rich in mineral ores, especially copper and gold along the entire central mountain chain, formed when the north-drifting Australian continental plate and the westward-moving Pacific complex of oceanic plates collided. During the collision, mountain-forming processes took place, and cracks and fissures opened up into which igneous material, under great pressure, rose and cooled (Mealey 1996: 218). Samples from the ore body - the 'Ertsberg', were rediscovered in the 1960s by the Freeport mining company, which led another expedition to survey the Mt Jaya area and assess its suitability for mining. After an agreement with the Indonesian government, mining of the Ertsberg began in the early 1970s, and subsequent exploration of the adjacent areas revealed many more mineral-rich areas; today, the PT-FI mine contains the largest single copper reserve and the largest single gold reserve of any mine in the world.

\section{Vegetation zones}

The PT-FI project area includes not only the mine areas at c. $4000 \mathrm{~m}$ but also a large area running to the south of the mountain range all the way to the coast, and is thus very rich in biodiversity with sea level habitats, such as mangrove and coastal forest, rising through lowland tropical rainforest, heath forest, and montane forest to subalpine and alpine habitats above $3000 \mathrm{~m}$. The Kew project collected in all these areas but most work was done in the subalpine and alpine habitats, and these are most relevant to this paper. The vegetation of Mt Jaya was described in great detail by Hope et al. (1976), and the reader is referred there for a full discussion. Subalpine habitats include areas of forest to $3700 \mathrm{~m}$, with remnants found to $4200 \mathrm{~m}$, and large areas of shrub-rich grasslands with the characteristic tree ferns scattered through the grassland. Alpine habitats start from c. $4200 \mathrm{~m}$ and include heath and herblands, and flat wet areas such as mires and bogs.

\footnotetext{
1 Herbarium, Royal Botanic Gardens, Kew, Richmond, Surrey, TW9 3AE, United Kingdom.
} 


\section{Glaciers}

During the last glacial maximum, at about 35000 years BP, the ice sheet on New Guinea covered c. 2000 km² $^{2}$ Verstappen 1964, Hope et al. 1976), and terminal moraines have been found as low as $1800 \mathrm{~m}$ (Johns pers. comm.). Mt Jaya, once covered by a single large ice sheet, still has five small glaciers, but these have been found to be rapidly retreating since 1912 ; in 1976 their area was c. $6.9 \mathrm{~km}^{2}$, reducing to c. $2.2 \mathrm{~km}^{2}$ in 2002 (Kincaid \& Klein 2004).

\section{THE KEW PROJECT}

Collaboration between the RBG Kew, Rio Tinto, and PT-FI was initiated in 1997 to undertake botanical survey work in the PT-FI area; specifically to produce a series of checklists and guides to the different habitat types in the concession. During the collaboration five expeditions were conducted, amassing c. 5000 new collections, and from these the checklists were written. A series of papers was published which described 25 new species and one new genus (e.g., Utteridge 2000a, b, 2001, 2002, 2003, Hind \& Johns 2002, 2003, Hind 2004, Chambers et al. 2005). The project culminated in the publication of the illustrated guide to the subalpine and alpine flora of Mt Jaya (Johns et al. 2006).

In addition to the taxonomic work, a database of all the collections, both contemporary and historical that have been made on Mt Jaya was compiled that allowed an analysis of collecting patterns over time to be undertaken (Utteridge \& De Kok 2007). Two patterns are worthy of comment. The first is the additional number of species that specialists can add to an inventory project. During the Kew expeditions, two members of the Kew team took part in every expedition and became knowledgeable of the flora, i.e. they became good generalist collectors. However, they still were unable to collect the full range of species in several difficult and species rich groups, especially Ericaceae, palms, grasses, sedges, and ferns. However, specialists on the field trips collected additional species in these groups that the generalists did not collect; thus it is important for inventory projects to initiate projects with generalists and then employ specialist collectors later in the project. The second pattern reflects the intrinsic human desire to climb mountains. During Kew's last expedition a period spent in the alpine region required 45 collected specimens before a new species was added to the project's list, whereas effort would have been better spent collecting in the montane zones where every 3.1 collections yielded a new species to the project's list; this is reflected in the collecting effort in the two zones on a plot of number of species added to the cumulative sample size (see Fig. 1). Initiating a data basing programme at the beginning of an inventory or Flora project will help to direct collecting effort and keep costs efficient (see Utteridge \& De Kok 2007).

\section{THE FLORA OF MT JAYA}

The subalpine and alpine flora of Mt Jaya above $3000 \mathrm{~m}$ is very rich with 710 taxa in 228 genera in 93 families recorded in the recently published guide (Johns et al. 2006), collected from an area of approximately $125 \mathrm{~km}^{2}$. (The number of taxa includes several problematic groups such as Tasmannia (Winteraceae) that are considered as entities rather than species; see Vink 1970.) The largest group is the dicotyledons (397 species, $56 \%$ of the total), followed by the monocotyledons (163 spp., $23 \%$ ), with a similar number of ferns (141 spp., $20 \%$ ); there are 9 gymnosperms in the region (1\%). The top ten most diverse families based on number of species, the number of genera and the percentage of those species that are endemic to New Guinea, are shown in Table 1. It is interesting to note that the ferns not only form a large percentage of the flora, but also contain the fifth richest group in the family Grammitidaceae, and the Thelypteridaceae as the 8th richest family; the ferns are discussed in greater detail below. The five largest genera on Mt Jaya are Rhododendron (44 spp.); Vaccinium (33 spp.); Poa (20 spp.); Dendrobium (17 spp.); and Potentilla (16 spp.). There are high levels of endemism in the New Guinea flora and this is reflected on Mt Jaya: a total of 537 species (77\% of the total Mt Jaya alpine flora) are endemic to New Guinea, and of these 123 species are endemic to Mt Jaya (17.5\% of the total).

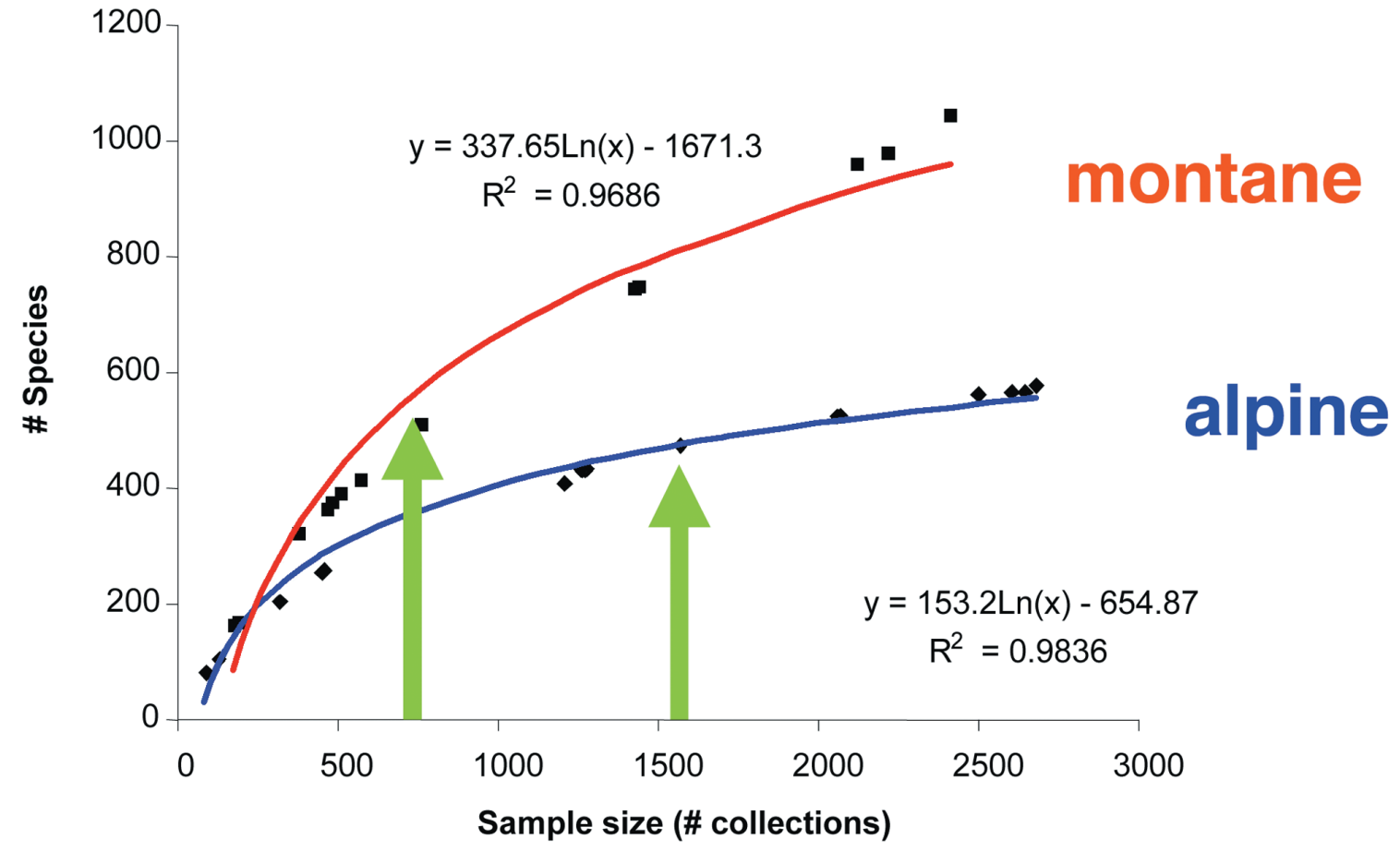

Fig. 1 Species accumulation data and curves for alpine and montane habitats of the Mt Jaya area. X-axis: cumulative number of collections; Y-axis: cumulative number of species. Alpine collections: diamonds, grey line; montane collections: squares, black line. Green arrows: Kew project starts. 
Table 1 Table showing the ten most species-rich families in the subalpine and alpine flora of Mt Jaya. The endemicity column shows the percentage of New Guinea endemics within the family on Mt Jaya.

\begin{tabular}{lccc}
\hline Family & No. of species & No. of genera & Endemicity \\
\hline Ericaceae & 96 & 5 & $100 \%$ \\
Orchidaceae & 89 & 23 & $94 \%$ \\
Compositae & 54 & 17 & $87 \%$ \\
Poaceae & 42 & 16 & $76 \%$ \\
Grammitidaceae & 34 & 6 & $41 \%$ \\
Rosaceae & 25 & 4 & $76 \%$ \\
Cyperaceae & 23 & 10 & $21 \%$ \\
Thelypteridaceae & 16 & 5 & $88 \%$ \\
Rubiaceae & 16 & 7 & $81 \%$ \\
Urticaceae & 15 & 6 & $66 \%$
\end{tabular}

\section{Fern diversity}

The 141 species of high altitude ferns and fern allies form a large proportion of the flora of Mt Jaya (20\%, see above), but prior to the publication of the Kew Guide to Mt Jaya, they have not been treated in any great detail - the Alpine Flora by Van Royen (1980) excluded them. In this section we expand on discoveries in several different families, and highlight some of the fern 'firsts', in the hope that interested workers are inspired to examine New Guinea's ferns and fern allies in the future.

From the Mt Jaya collections made by the Kew team in the period from 1998-2002, to date a total of 29 new or very probably new taxa have been identified, with some already described (Parris 2004, Chambers et al. 2005); a similar number of new species is likely to be found once the ongoing research into several taxa, especially the problematic groups of the Thelypteridaceae and the genus Polystichum, is complete. In addition five old names have been synonymised, with more synonymy to follow based on research for the flora. Many of the collections represent new records or provide materials for study in particularly difficult groups. For example, one of the four Mt Jaya project collections of Selaginella phanotricha Baker (Selaginellaceae) represents the world altitude record for a Selaginella collection with $3540 \mathrm{~m}$ (the former record being $340 \mathrm{~m}$ lower).

Amongst the new species discovered during the Kew expeditions are some particularly interesting new plants. For example, the collections of Woodwardia sp. (Blechnaceae) are the first record of this genus from New Guinea, and show a remarkable disjunction for a fern genus - Woodwardia being known from the Northern hemisphere South to Indochina (Cranfill \& Kato 2003). Blechnum puniceum (Blechnaceae) was recorded shortly after the revision of the Malesian species by Chambers \& Farrant (2001). Affinities of this new species are, surprisingly, with the much larger and low altitude species $B$. nesophilum T.C.Chambers \& P.A.Farrant from the islands of NE New Guinea and the Solomons, and itself only described in 2001. In addition, within Cyathea s.l. there are at least five new species awaiting formal description; the many collections of Sphaerostephanos represent at least 6 new taxa; a very distinctive new species of Plesioneuron (Thelypteridaceae) was also discovered; and within Polystichum (Dryopteridaceae) two probable new species were discovered.

Excluding the new species, the Mt Jaya project collections yielded 9 first records of species for Papua, and 21 second records for the province. The Grammitidaceae are a family of small epiphytes, and of the 34 species recorded for Mt Jaya, three are first records for Papua, and $12(35 \%)$ are only the second locality records for Papua, illustrating, as for other genera, either the special fern floristics of Mt Jaya, or the lack of collecting in Papua. The terrestrial fern Plagiogyria glauca (Blume) Mett. (Plagiogyriaceae) is a conspicuous and easily

recognised species, known to be common and widespread from N India to China through Malesia to Guadalcanal, but the many recent Mt Jaya collections of this represent only the second locality record of the species for Papua.

Many of the collections may not represent new species or new records but will allow future workers to understand variation in some difficult groups. For example, the many Selliguea (Polypodiaceae) collections made will help to illuminate some of the questions posed by Hovenkamp (1998) regarding relationships in this very plastic genus of epiphytes. In the Thelypteridaceae many excellent collections have helped enlarge our very sparse knowledge of Coryphopteris stereophylla, Plesioneuron pullei, and Pneumatopteris petrophila. The genus Stenolepia (Dryopteridaceae) is an overlooked small genus of large ferns, and the excellent collections made in the Mt Jaya project will help to provide a firm foundation a badly needed revision of this genus (the majority of collections have been made only in the last 40 years and languish unnamed in herbaria).

It is clear that these collections from Indonesian New Guinea highlight our lack of understanding in New Guinea's high altitude ferns, have brought to light many new taxa, and may help to explain many of the distribution anomalies. Our work on Mt Jaya's subalpine and alpine ferns and fern allies has shown how many more novelties exist in Papua, even for these high altitudes, where this sporiferous group could reasonably be expected to consist predominantly of widely distributed species. We must also note that of the collections made at lower altitudes in lowland and montane forests, which have yet to be worked on, there are many more new species as well as first and second records for Papua.

\section{CONSERVATION ISSUES}

In the Guide to Mt Jaya, the conservation status of each species was evaluated according to the IUCN (2001) categories, which are: DD - data (on distribution and threat) deficient; LC - least concern; NT - near threatened; VU - vulnerable; EN endangered; CR - critically endangered; NE - not evaluated; the distribution of these categories in shown in Fig. 2. On Mt Jaya, $18 \%$ of the flora falls within one of the threat categories, with most of these assigned to NT or VU, the lowest threat status; 14 species are considered to be critically endangered with most of these being Mt Jaya endemics (Table 2). Approximately $20 \%$ of the alpine flora of Mt Jaya falls into the category of NE or DD, with many of the NE species suffering from insufficient taxonomic data, and those of DD being species which are known from very few collections; it is possible with further work on the flora many of these species will fall into a threat category.

Table 2 The critically endangered species of Mt Jaya.

\section{Coprosma barbata Utteridge}

Glossorhyncha monticuprina P.Royen Novaguinea rudalliae D.J.N.Hind Papuacalia milleri D.J.Hind \& R.J.Johns Pedilochilus macrorhinum P.Royen Pittosporum spissescens Utteridge Platanthera alpinipaludosa P.Royen Rhododendron carstensense Wernham Rhododendron cyrtophyllum Wernham Sericolea ovalifolia (Wernham) Gibbs var. ovalifolia

Tasmannia piperita (Hook.f.) Miers entity elongate

Timonius klossii Wernham

Trigonotis minuta (Wernham) I.M.Johnst. Wittenstinia papuana (Steenis) Steenis
(Rubiaceae; Mt Jaya endemic) (Orchidaceae; Mt Jaya endemic) (Asteraceae; New Guinea endemic) (Asteraceae; Mt Jaya endemic) (Orchidaceae; Mt Jaya endemic) (Pittosporaceae; Mt Jaya endemic) (Orchidaceae; Mt Jaya endemic) (Ericaceae; Mt Jaya endemic) (Ericaceae; Mt Jaya endemic) (Elaeocarpaceae; Mt Jaya endemic)

(Winteraceae; New Guinea endemic)

(Rubiaceae; Mt Jaya endemic) (Boraginaceae; Mt Jaya endemic) (Alseuosmiaceae; New Guinea endemic) 


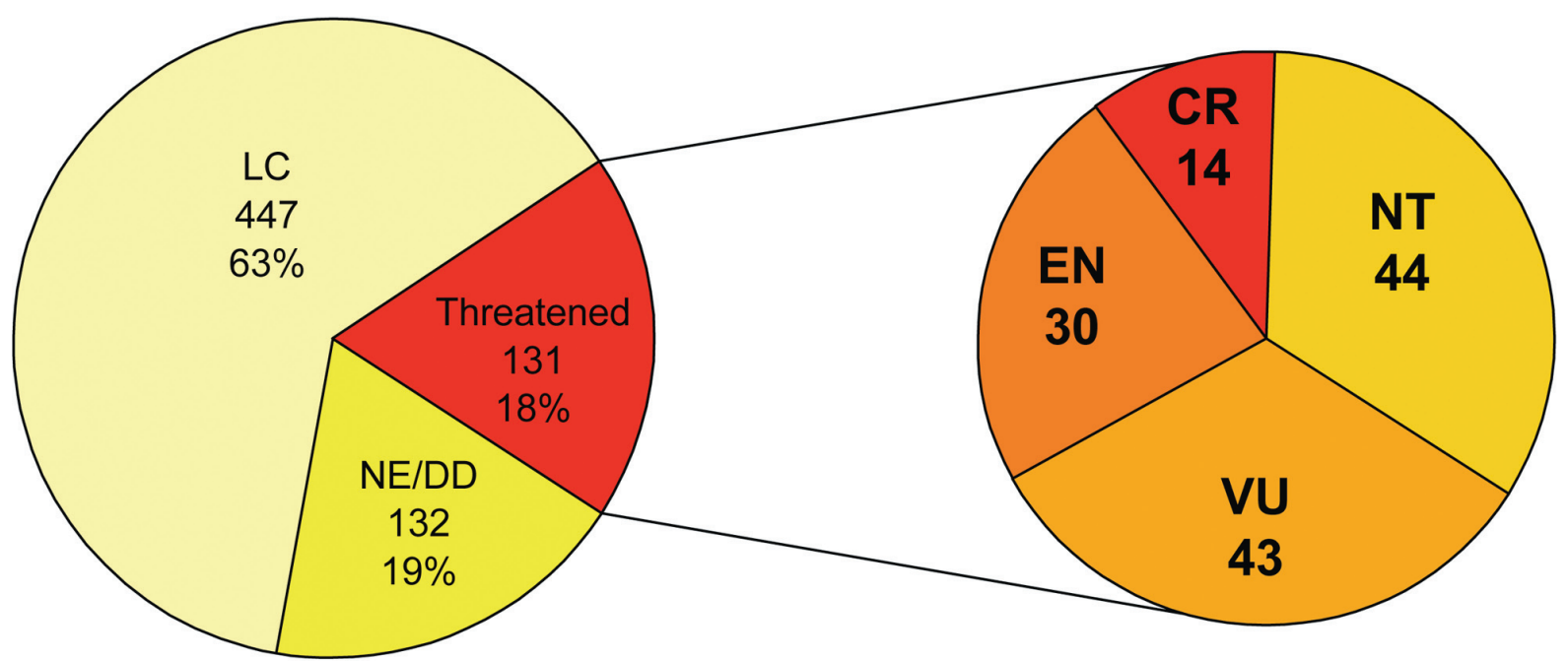

Fig. 2 Pie charts showing the conservation status of the subalpine and alpine flora of Mt Jaya using IUCN categories of threat. Left: total number of species in the categories least concern (LC), not evaluated and data deficient (NE/DD) and threatened. Right: number of species in threat categories critically endangered (CR), endangered (EN), vulnerable (VU) and near threatened (NT).

For subalpine and alpine species with restricted distributions, changes in population decline and reduction in geographical distribution are possible. The main factor is direct human action and climate change. Climate change will cause changes in temperature, length of seasons and nitrogen levels, and is likely to increase the amount of alpine habitats available to 'invaders' from lower altitudes whilst at the same time create pressure for upward migration (Körner 1999). However, direct human action on alpine habitats will have the most immediate impact on the flora of Mt Jaya, particularly mining activities by PT-FI. Obviously, habitats associated with the Ertsberg and Grasberg mine areas no longer exist, and adjacent habitats are also threatened by mine activities, including for example the dumping of mine overburden from the Grasberg pit onto the Carstensz Meadow and upper Wanagon Valley. Further ore deposits have been found at high altitude in the Mt Jaya region and their future exploitation might further reduce the habitat of some species. Conservation plans will be needed for the subalpine and alpine flora of Mt Jaya, especially for those species endemic to Mt Jaya, if these plants are to survive.

Acknowledgements We would like to thank Rio Tinto and PT-Freeport Indonesia whose generous contributions to the Mt Jaya project at Kew allowed us to visit Mt Jaya. We would like to especially thank members of the PT-Freeport Indonesia Environmental Department who aided us considerably during fieldwork. We would like to thank colleagues at Kew who helped us during the preparation of the conference presentation and writing this paper especially Rogier de Kok, Melanie Thomas, Gemma Bramley, Alison Moore, Sophie Marsh, Neil Brummitt, and Clare Drinkell. We would also like to thank Peter Hovenkamp for his critical reading of the paper and his helpful suggestions during the review process.

\section{REFERENCES}

Ballard C, Ploeg A, Vink S (eds). 2002. Race to the snow: photography and exploration of Dutch New Guinea, 1907-1936. Koninklijk Instituut voor de Tropen, Amsterdam.

Chambers TC, Edwards PJ, Johns RJ. 2005. Blechnum puniceum (Pterophyta: Blechnaceae), a new species from Papua, Indonesia. Contributions to the Flora of Mount Jaya, XVI. Kew Bulletin 60: 597-601.

Chambers TC, Farrant PA. 2001. Revision of Blechnum (Blechnaceae) in Malesia. Blumea 46: 283-350.

Cranfill R, Kato M. 2003. Phylogenetics, biogeography and classification of the woodwardioid ferns (Blechnaceae). In: Chandra S, Srivastava M (eds), Pteridology in the new millennium: 25-48. Kluwer Academic, Dordrecht. Hind DJN. 2004. Novaguinea (Compositae: Astereae: Lagenophorinae), a new endemic genus to Papua, Indonesia. Contributions to the Flora of Mount Jaya, XIII. Kew Bulletin 59: 177-188.
Hind DJN, Johns RJ. 2002. A new alpine species of Ixeridium (Compositae: Lactuceae). Contributions to the Flora of Mount Jaya, VIII. Kew Bulletin 57: 697-703.

Hind DJN, Johns RJ. 2003. New species of Papuacalia (Compositae: Senecioneae). Contributions to the Flora of Mount Jaya, XI. Kew Bulletin 58: 389-402.

Hope GS, Peterson JA, Allison I, Radok U (eds). 1976. The equatorial glaciers of New Guinea. Balkema, Rotterdam.

Hovenkamp P. 1998. An account of the Malay-Pacific species of Selliguea (Polypodiaceae). Blumea 43: 1-108.

IUCN. 2001. IUCN Red List Categories and Criteria: v3.1. IUCN Species Survival Commission. IUCN, Gland, Switzerland, Cambridge, England.

Johns RJ, Edwards PJ, Utteridge TMA, Hopkins HF. 2006. A guide to the alpine and subalpine Flora of Mount Jaya. Kew Publishing, Royal Botanic Gardens, Kew.

Kincaid JL, Klein AG. 2004. Retreat of the Irian Jaya glaciers from 2000 to 2002 as measured from IKONOS satellite images. Proc. 61st Eastern Snow Conference: 147-157. (http://www.easternsnow.org/proceedings/2004/ proceedings_index.html)

Körner C. $199 \overline{9}$. Alpine plant life. Springer, Berlin.

Mealey G. 1996. Grasberg: Mining the richest and most remote deposit of copper and gold in the world, in the mountains of Irian Jaya, Indonesia. Freeport-McMoRan Copper \& Gold, New Orleans.

Mittermeier RA, Brooks TM, Pilgrim JD, Konstant WR, Da Fonseca GAB, Kormos C. 2003. Wilderness and biodiversity conservation. PNAS 100: 10309-10313.

Parris BS. 2004. Three new species of Grammitidaceae (Filicales) from New Guinea. Contributions to the Flora of Mount Jaya, XV. Kew Bulletin 59: 219-222.

Utteridge TMA. 2000a. Two new species of Maesa (Myrsinaceae) from Puncak Jaya, New Guinea. Contributions to the Flora of Mt Jaya, I. Kew Bulletin 55: 443-449.

Utteridge TMA. 2000b. The subalpine members of Pittosporum (Pittosporaceae) from Mt Jaya, New Guinea. Contributions to the Flora of Mt Jaya, II. Kew Bulletin 55: 699-710.

Utteridge TMA. 2001. A new species of Medusanthera Seem. (Icacinaceae) from New Guinea: Medusanthera inaequalis Utteridge. Contributions to the Flora of Mt Jaya, IV. Kew Bulletin 56: 233-237.

Utteridge TMA. 2002. New species of Coprosma (Rubiaceae) from New Guinea. Contributions to the Flora of Mt Jaya, VII. Kew Bulletin 57: 195-203. Utteridge TMA. 2003. Maesa from New Guinea: a new species and a revised description of Maesa beamanii. Contributions to the Flora of Mt Jaya, X. Kew Bulletin 58: 237-241.

Utteridge TMA, De Kok RPJ. 2007. Where do we go from here - and how often? In: Hodkinson TR, Parnell JAN (eds), Reconstructing the tree of life: taxonomy and systematics of species rich taxa: 291-298. CRC press, Boca Raton.

Van Royen P (ed). 1980. The alpine Flora of New Guinea. Cramer, Vaduz. Verstappen HTh. 1964. Geomorphology of the Star Mountains. Nova Guinea, Geology 5: 101-158.

Vink W. 1970. The Winteraceae of the Old World I. Pseudowintera and Drimys - morphology and taxonomy. Blumea 18: 225-354. 
